\title{
Phytochemical Properties and Proximate Composition of Papaya (Carica papaya L. var solo 8) Peels
}

\author{
Adingra Kouassi Martial-Didier ${ }^{1}$, Konan Kouassi Hubert ${ }^{2 *}$, Kouadio Eugène Jean Parfait ${ }^{2}$, \\ Tano Kablan ${ }^{1}$
}

${ }^{1}$ Laboratoire de Biochimie Alimentaire et de Technologie des Produits Tropicaux de l'Université Nangui Abrogoua (Abidjan, Côte d'Ivoire), 22 BP 801 Abidjan 22, Côte d'Ivoire.

${ }^{2}$ Laboratoire de Biocatalyse et des Bioprocédés de l'Université Nangui Abrogoua (Abidjan, Côte d'Ivoire), 22 BP 801 Abidjan 22, Côte d'Ivoire.

A R T ICLE IN F O \begin{abstract}
A B S T R A C T
Papaya (Carica papaya) is a common tropical fruit used for nutrition as well as medicinal purposes. Apart from fruit, seed, latex and other plant parts of papaya tree have been shown to have medicinal properties. Since, no systematic study has been performed on nutritional analysis of papaya (Carica papaya L. var solo 8) peels. In this study, the proximate composition, mineral element profile and phytochemical composition of papaya (Carica papaya L. var solo 8) peels were investigated. The peels were harvested fresh, dried in an oven at $45^{\circ} \mathrm{C}$ for 48 hours, ground and analyzed according to standard procedures. Proximate analysis showed high level of proteins $(11.67 \pm 0.04 \%)$, crude fibre $(32.51 \pm 0.03 \%)$, carbohydrate $(47.33 \pm 0.08 \%)$, ash $(5.98 \pm 0.03 \%) 0.03 \%)$ and fat $(2.51 \pm 0.13 \%)$. Mineral analysis indicated the papaya (Carica papaya L. var solo 8 ) peels were specifically rich in potassium and phosphorus. Potassium was found to be the most abundant mineral present in the peels $(516.33 \pm 0.82 \mathrm{mg} / 100 \mathrm{~g})$. Phytochemical composition showed high level of total phenolic $(65.48 \pm 0.39 \mathrm{mg}(\mathrm{GAE}) / 100 \mathrm{~g} \mathrm{DW})$, flavonoids $(5.58 \pm 0.83 \mathrm{mg}(\mathrm{QE}) / 100 \mathrm{~g} \mathrm{DW})$ and tannins $(10.51 \pm 0.93 \mathrm{mg}(\mathrm{TAE}) / 100 \mathrm{~g}$ DW). The methanolic extracts of the papaya (Carica papaya L. var solo 8) peels exhibited the high DPPH radical scavenging activities $(81.89 \pm 0.14 \%)$. These data indicated that this papaya (Carica papaya L. var solo 8) peels could constitute a potential good source of natural antioxidant for local population.
\end{abstract}

Research Article

Received 04 January 2017

Accepted 12 April 2017

Keywords:

Antioxidant activity

Papaya

Peel

Phytochemical composition

Proximate composition

*Corresponding Author:

E-mail: h_k_konan@yahoo.fr

DOI: https://doi.org/10.24925/turjaf.v5i6.676-680.1154

\section{Introduction}

In recent years, the role and beneficial effects of many phytonutrients from plant sources such as fruits and vegetables had attracted much attention from food scientists as well as the public. These phytochemicals are natural antioxidant which frequently promoted due to the concerns regarding toxicity of the synthetic ones. Apart from free radical scavenging activity, antioxidants found from most of the plants possess antibacterial, antiviral, antimetastasis activity, antiulcer activity, antimutagenic, antiallergic and anticarciogenicity (Moure et al., 2001).

Increasing numbers of studies on residual sources in replacing synthetic antioxidants with the natural ones are due to the augmented recycling interest of the agro-food industry. These are playing an important role in improving the complete utilization of the residual sources. The wastes or by-products from food processing such as seed and peel of some fruits contain higher source of potential antioxidant activities than that the edible portion (Okonogi et al., 2007).
Carica papaya L. belongs to the family of Caricaceae. It is an herbaceous plant that grows in tropical and subtropical countries (Da Silva et al., 2007). Nutritionally, the major components of papaya fruit pulp dry matter are carbohydrates. At the early stage of fruit development, glucose is the main sugar but the sucrose content increases during ripening and can reach up to $80 \%$ of the total sugars. The edible portion of the ripe papaya fruit contains both macro and micro minerals and these are $\mathrm{Na}$, $\mathrm{K}, \mathrm{Ca}, \mathrm{Mg}, \mathrm{P}, \mathrm{Fe}, \mathrm{Cu}, \mathrm{Zn}$ and $\mathrm{Mn}$. Carica papaya is a source of carotenoids, vitamin $\mathrm{C}$, thiamine, riboflavin, niacin, vitamin $B_{6}$ and vitamin $K$ (Bari et al., 2006). Ripe papaya is most commonly consumed as fresh fruit whereas green papaya as vegetable usually after cooking or boiling (Anuar et al., 2008).

Papaya, as a tropical fruit, was traditionally used as therapeutic remedy due to its medicinal properties. The fruit is rich in phytochemicals, especially carotenoids and polyphenols (Sancho et al., 2011). Papaya is also known to be a thirst quencher by people living in tropical 
countries. Besides its juicy pulp, the peel and seeds of papaya are valuable too. Papaya seeds were known to give several health benefits (Adebiyi et al., 2003; Thomás et al., 2009). In some of the poor countries in tropical region, papaya peel is used for cooking as one of the dishes. The increase in processing of papaya pulp necessitates the determination of the potential of papaya peel utilization in human and /or animal diets. Therefore, the aim of this study was to determine the proximate constituent and phytochemicals that are present in papaya (Carica papaya L. var solo 8) peel flour. This will help in determining of its medicinal and nutritional values which may be useful in pharmaceutical and food industries.

\section{Materials and Methods}

\section{Collection of Fruit And Sampling}

The papayas (Carica papaya L. var solo 8) were harvested from a farm near Thomasset (Azaguié), a village located at about $50 \mathrm{~km}$ north of Felix Houphouet Boigny Airport, Abidjan, Cote d'Ivoire. The fruit were transported directly to the Biocatalysis and Bioprocessing laboratory of Nangui Abrogoua University (Côte d'Ivoire). They were selected according to the mature stage (1/8 fruit with yellow skin) proposed by N'da et al. (2008), average size, and absence of defects. The selected fruits were washed thoroughly to free from mud, ferns and other extraneous material, dried on blotting paper. They were then manually peeled; the peels were cut and washed with running water to remove mucilage. After washing, they were dried in an oven at $45^{\circ} \mathrm{C}$ for 48 hours. The dried samples were mechanically milled into powder with flat-hammer grinding mill and sifted through a 60mesh screen and then stored in airtight containers for analysis (AOAC, 1995).

\section{Proximate Composition Analysis}

Dry matters were determined by drying in an oven at $105^{\circ} \mathrm{C}$ during $24 \mathrm{~h}$ to constant weight (AOAC, 1990). Crude protein was calculated from nitrogen $(\mathrm{N} \times 6.25)$ obtained using the Kjeldahl method by AOAC (1990). Crude fat was determined by continuous extraction in a Soxhlet apparatus for $8 \mathrm{~h}$ using hexane as solvent (AOAC, 1990). Total carbohydrates were calculated by difference. Total ash was determined by incinerating in a furnace at $550^{\circ} \mathrm{C}$ (AOAC, 1990). Method described by Dubois et al. (1956) was used to determine total sugars while reducing sugars were analyzed according to the method of Bernfeld (1955) using 3.5 dinitrosalycilic acids (DNS). The crude fibre contents were determined according to standard method (AOAC, 1990).

\section{Minerals Analysis}

Minerals were determined employing AOAC (1990) method. Flour was digested with a mixture of concentrated nitric acid (14.44 mol/L), sulfuric acid (18.01 mol/L) and perchloric acid $(11.80 \mathrm{~mol} / \mathrm{L})$ and analyzed using an atomic absorption spectrophotometer. The total phosphorus was determined as orthophosphate by the ascorbic acid method after acid digestion and neutralization using phenolphthalein indicator and combined reagent (APHA, 1995).

\section{Phytochemical Composition}

Extraction of phenolic compounds: Extraction of phenolic compounds were determined employing Singleton et al. (1999) method. A sample (10 g) of finedried papayas peels flour was extracted by stirring with $50 \mathrm{ml}$ of methanol $80 \%(\mathrm{v} / \mathrm{v})$ at $25^{\circ} \mathrm{C}$ for 24 hours and filtered through Whatman no 4 paper. The residue was then extracted with two additional $50 \mathrm{ml}$ portions of methanol. The combined methanolic extracts were evaporated at $35^{\circ} \mathrm{C}$ (rotary evaporator HEILDOLPH Laborata 4003 Control, Schwabach, Germany) until 25 $\mathrm{ml}$, prior to phenolic compound contents determination.

Determination of total phenolic compounds content: Contents of total phenolic compounds were estimated according Folin-Ciocalteu method (Singleton et al., 1999). A volume of $1 \mathrm{ml}$ of methanolic extract of each sample was added to $1 \mathrm{ml}$ of Folin-Ciocalteu's solution in a test tube. After 3 minutes, $1 \mathrm{ml}$ of $20 \%$ sodium carbonate solution was added to the mixture and adjusted to $10 \mathrm{ml}$ with distilled water. The mixture was allowed to stand at room temperature in a dark environment for 30 min. Absorbance was measured against the blank reagent at $725 \mathrm{~nm}$. Gallic acid was used for the calibration curve with a concentration range of 50-1000 $\mu \mathrm{g} / \mathrm{ml}$. Results were expressed as $\mathrm{mg}$ gallic acid equivalent (GAE)/100g DW (Dry Weight).

Determination of flavonoids: Total flavonoids content was determined according method used by Meda et al. (2005), but slightly modified. A volume of $0.5 \mathrm{ml}$ of methanolic extract of sample was diluted in $0.5 \mathrm{ml}$ of distilled water. Then, $0.5 \mathrm{ml}$ of aluminium chloride $10 \%$ $(\mathrm{P} / \mathrm{V})$ and the same volume of sodium acetate $1 \mathrm{M}$ were added. Finally, $2 \mathrm{ml}$ of distilled water was added and absorption reading at $415 \mathrm{~nm}$ was carried out after $30 \mathrm{~min}$ against a blank sample consisting of a $4 \mathrm{ml}$ methanolic extract without aluminum chloride. Quercetin was used for the calibration curve with a concentration range of 0 $100 \mu \mathrm{g} / \mathrm{ml}$. Results were expressed as $\mathrm{mg}$ of quercetin equivalent $(\mathrm{QE}) / 100 \mathrm{~g}$ DW.

Determination of tannins: Tannins content was determined using the method described by Bainbridge et al. (1996). A volume of $1 \mathrm{ml}$ of each methanolic extract was collected and mixed with $5 \mathrm{ml}$ of reaction solution [vanillin $0.1 \mathrm{mg} / \mathrm{ml}$ in sulphuric acid $70 \%(\mathrm{~V} / \mathrm{V})$ ]. The mixture was allowed to stand at room temperature in a dark environment for $20 \mathrm{~min}$. The absorbance was measured at $500 \mathrm{~nm}$ against a blank (without extract). Tannic acid was used for the calibration curve with a concentration range of $0-100 \mu \mathrm{g} / \mathrm{ml}$. The results were expressed as mg of tannic acid equivalents (TAE)/100 g DW.

Estimation of antioxidant activity by DPPH radical scavenging: The DPPH scavenging activity was determined using the method described by Shimada et al. (1992). Each sample of methanolic extract $(2.5 \mathrm{ml})$ was mixed with $1 \mathrm{ml}$ of a $3 \mathrm{mM}$ DPPH methanol solution. After 30 min incubation at room temperature in the dark, the absorbance of the mixture was determined at $517 \mathrm{~nm}$ against a blank containing methanol without DPPH radical. A lower absorbance indicates a higher scavenging 
activity. Absorbance was converted to the DPPH radicalscavenging rate according to the equation:

DPPH radical scavenging rate $(\%)=[$ (AcontrolAsample)/Acontrol] x100.

\section{Statistical Analysis}

All chemical analyses and assays were performed in triplicate, unless otherwise indicated. Results were expressed as mean values $\square \pm$ standard deviation (SD). Analysis of variance (ANOVA) followed by Duncan's test was performed to test for differences between means by employing Kyplot (version 2.0 beta 15, c1997-2001, Koichi Yoshioka) statistical software.

\section{Results and discussion}

\section{Proximate composition}

The results of the proximate composition analysis of papayas peels were presented in Table 1. The moisture content of papaya (Carica papaya L. var solo 8) peel flour was $9.82 \pm 0.09 \%$ DW (Dry Weight). Papaya peel flour can be easily stockpiled for a longer period because it is resistant to mould growth, as it has a low moisture percentage (5-10) (Werthera et al., 2000).

The carbohydrate content of papaya (Carica papaya L. var solo 8) peel flour was $47.33 \pm 0.08 \%$. The result shows significant amount of carbohydrate in the flour from papayas peels and hence they can be utilized as a source of carbohydrate. Carbohydrate concentration was higher than the flour of peels from two papaya cultivars in the studies of Santos et al. (2014).

Protein content, with its sufficiency in a diet indicating its adequacy and quality was $11.67 \pm 0.04 \%$ DW in the papaya peel flour studied. This result differ from those found in papaya peel by Silva et al. (2007), who reported values between 6 to $9 \%$ in the peel. On the other hand, Rinaldi et al. (2010) found higher values for Formosa and Papaya peels: 25.35 and $32.5 \%$ respectively. The proper recycling of papaya peel in the present study could lead to many economical protein containing products.

In the present study, the fibre content was $32.51 \pm$ $0.03 \% \mathrm{DW}$. The high content of dietary fiber is noteworthy in the papaya (Carica papaya L. var solo 8) peel flour. This result show the importance of the peel as a source of dietary fiber since, according to ANVISA (Agência Nacional de Vigilância Sanitária, 2012), food with a content of $6 \%$ can be considered high in fiber.

The ash content was $5.98 \pm 0.03 \%$ DW. This ash content was lower compared to those reported by Santos et al. (2014) on two papaya cultivars: Havai (11.85\%) and Calimosa $(11.31 \%)$.

\section{Mineral Composition}

The mineral content of papaya (Carica papaya L. var solo 8) peel flour was shown in Table 2. The Potassium concentration was found the highest $(516.33 \pm 0.82$ $\mathrm{mg} / 100 \mathrm{~g}$ of DW product) as compared to all the other minerals content, followed by Phosphorus (221.54 \pm 0.85 $\mathrm{mg} / 100 \mathrm{~g}$ of DW product) in the analyzed peel flour. High amount of potassium in the body was reported to increase iron utilization (Adeyeye, 2002) and beneficial to control hypertension through body fluid (Arinathan et al., 2003). Godim et al. (2005) analyzed the mineral composition of Papaya peels and reported values higher for calcium $(55.41 \mathrm{mg} / 100 \mathrm{~g})$, iron $(1.41 \mathrm{mg} / 100 \mathrm{~g})$, sodium $(53.24$ $\mathrm{mg} / 100 \mathrm{~g}$ ) and magnesium (24.52 Magnesium) than those found for the papaya (Carica papaya L. var solo 8) peel flour.

Table 1 Proximate chemical composition of flours from peels of solo papaya 8 (Carica papaya).

\begin{tabular}{l|c}
\hline \multicolumn{1}{c|}{ Parameters } & Values $(\mathrm{g} / 100 \mathrm{~g})$ \\
\hline Moisture $(\%)$ & $9.82 \pm 0.09$ \\
Total sugars & $1.78 \pm 0.63$ \\
Reducing sugars & $1.03 \pm 0.42$ \\
Total fiber & $32.51 \pm 0.03$ \\
Ash & $5.98 \pm 0.03$ \\
Proteins & $11.67 \pm 0.04$ \\
Fat & $2.51 \pm 0.13$ \\
Carbohydrates & $47.33 \pm 0.08$ \\
\hline
\end{tabular}

Mean \pm standard deviation of three determinations.

Table 2 Mineral contents of flours from peels of solo papaya 8 (Carica papaya)

\begin{tabular}{l|c}
\multicolumn{1}{c}{ Mineral contents } & $\mathrm{mg} / 100 \mathrm{~g}$ of dry weight product \\
\hline Calcium & $18.61 \pm 0.78$ \\
Phosphorus & $221.54 \pm 0.85$ \\
Zinc & $1.97 \pm 0.21$ \\
Potassium & $516.33 \pm 0.82$ \\
Magnesium & $19.11 \pm 0.44$ \\
Sodium & $9.61 \pm 0.73$ \\
Iron & $0.65 \pm 0.37$ \\
\hline
\end{tabular}

Mean \pm standard deviation of three determinations.

Table 3 Phytochemical composition of flours from peels of solo papaya 8 (Carica papaya)

\begin{tabular}{l|c}
\hline \multicolumn{1}{c|}{ Parameters } & Values of dry weight product \\
\hline $\begin{array}{l}\text { Total polyphenols } \\
(\mathrm{mgGAE} / 100 \mathrm{~g} \text { DW })\end{array}$ & $65.48 \pm 0.39$ \\
$\begin{array}{l}\text { Antioxidant activity } \\
(\%)\end{array}$ & $81.89 \pm 0.14$ \\
$\begin{array}{l}\text { Flavonoids } \\
(\mathrm{mgQE} / 100 \mathrm{~g} \text { DW })\end{array}$ & $5.58 \pm 0.83$ \\
$\begin{array}{l}\text { Tannins } \\
(\mathrm{mgTAE} / 100 \mathrm{~g} \mathrm{DW})\end{array}$ & $10.51 \pm 0.93$ \\
\hline
\end{tabular}

Mean \pm standard deviation of three determinations.

\section{Phytochemical Composition}

The total phenolic contents for the investigated papaya peel flour were estimated by the Folin-Ciocalteu methods using the methanolic extracts are indicated in Table 3. The value was $65.48 \pm 0.39 \mathrm{mg}(\mathrm{GAE}) / 100 \mathrm{~g}$ DW. In order to obtain more information on the nature of phenolic compounds, the contents of total flavonoids and tannins were also estimated. Total flavonoids contents were found to be $5.58 \pm 0.83 \mathrm{mg}(\mathrm{QE}) / 100 \mathrm{DW}$ (Table 3). However, it is worth noting that flavonoids determination is highly selective for flavonoid structure since the 
isoflavone derivatives give no color with aluminum chloride (Balbaa et al., 1974). Regarding tannin contents, results indicated content values of $10.51 \pm 0.93 \mathrm{mg}$ (TAE)/100g DW (Table 3). From these results, it was noted that the papaya peel flour had relatively high contents of total phenolic compounds; this could be attributed in part to the nature of the extraction solvent used. Indeed, $\mathrm{Ng}$ et al. (2012) reports have indicated that methanol is considered to be one of the best solvents for extraction of total phenolic compounds in Carica papaya peel. This high contents of phenolic compounds found in papaya (Carica papaya L. var solo 8) peel flour could constitute interesting data for population nutrition since it is well-known that these bioactive compounds found in human diet act as the antioxidant compounds and play a role in stabilizing lipid peroxidation (Yen et al., 1993; Gulcin et al., 2003). Regarding flavonoids, they probably belong to the most interesting groups of natural phenolic compounds. Indeed, flavonoids are recognized to act as an antioxidant by breaking the radical chains and more stable products in the membranes of liver microsomes (Van Acker et al., 1998), and also to play an important role to the instinctive protection against oxidative stress (Arbaayah and Umi, 2013).

DPPH is a free radical compound that has been widely used to determine the free radical-scavenging ability of various samples (Amarowicz et al., 2004). The free radical scavenging activity determined by DPPH was expressed as the EC50 value (the effective concentration of extract required to inhibit $50 \%$ of the initial DPPH free radical). Results are shown in Table 3. The EC50 value of papaya (Carica papaya L. var solo 8) peel flour extract was $81.89 \pm 0.14 \%$, which was higher than those reported by Alothman et al. (2009); Choo and Azis (2010). However, this result was consistent with those reported Ang et al. (2012).

\section{Conclusion}

Based on the above results, it could be concluded that the papaya (Carica papaya L. var solo 8) peel flour could be used as a potential source for functional food ingredients and, in addition, it could be further processed into therapeutic functional food products.

\section{References}

Adebiyi A, Adaikan PG, Prasad RNV. 2003. Tocolytic and toxic activity of papaya seed extract on isolated rat uterus. Life Sci, 74: $581-592$.

Adeyeye EI. 2002. Determination of the chemical composition of the nutritionally valuable parts of male and female common West African fresh water crab Sudananautes africanus africanus. Int J Food Sci Nutr, 53: 189-196.

Agência Nacional de Vigilância Sanitária - Anvisa. (2012) Dispõesobre o Regulamento Técnico sobre Informação Nutricional Complementar (Resolução RDC $\mathrm{n}^{\circ}$ 54, de 12 de novembro de 2012). Diário Oficial da União. Retrieved from http://portal.anvisa.gov.

$\mathrm{br} / \mathrm{wps} / \mathrm{wcm} / \mathrm{connect} / 630 \mathrm{a} 98804 \mathrm{~d} 7065 \mathrm{~b} 981 \mathrm{f1e} 1 \mathrm{c} 116238 \mathrm{c} 3 \mathrm{~b} /$ Resolucao+RDC+n.+54_2012.pdf?MOD=AJPERES, (Accessed on September 27, 2016).
Alothman M, Bhat R, Karim AA. 2009. Antioxidant capacity and phenolic content of selected tropical fruits from Malaysia, extracted with different solvents. Food Chem, 115 (3): 785-788.

Amarowicz R, Pegg RB, Rahimi-Moghaddam P, Barl B, Weil JA. 2004. Free-radical scavenging capacity and antioxidant activity of selected plant species from the Canadian prairies. Food Chem, 84 (4): 551- 562.

Ang YK, Sia WC, Khoo HE, Yim HS. 2012. Antioxidant Potential of Carica Papaya Peel and Seed. Focus Mod Food Indus, 1 (1):11-16.

Anuar NS, Zahari SS, Taib IA, Rahman MT. 2008. Effect of Green and Ripe Carica papaya Epicarp Extracts on Wound Healing and during Pregnancy. Food Chem Toxicol, 46: 2384-2389.

AOAC. 1990. Association of Official Analytical Chemists. Official Methods of Analysis (15 th edn) Washington DC. 771p.

AOAC. 1995. Officiel Method of Analysis. Association of Agricultural Chemist. Washington D.C., 34.

APHA. 1995. Standard methods for examination of water and waste water, 19th ed., American Public Health Association, USA, 113-11.

Arbaayah HH, Umi KY. 2013. Antioxidant properties in the oyster mushrooms (Pleurotus spp.) and split gill mushroom (Schizophyllum commune) ethanolic extracts. Mycosphere, 4: 661-673.

Arinathan V, Mohan VR, John De Britto A. 2003. Chemical composition of certain tribal pulses in South India. Int J Food Sci Nutr, 54: 209-217.

Bainbridge Z, Tomlins K, Willings K, Westby A. 1996. Methods for assessing quality characteristics of non-grain starch staple. Part 4 advanced methods. National resources institute, University of Greenwich, UK ISBN 0-85954-400-, 43-79.

Balbaa AY, Zaki AY, Shamy AM. 1974. Qualitative and quantitative study of the flavonoid content of the different organs of Sophora japonica at different stages of development. Planta Med, 25: 325-330.

Bari L, Hassen P, Absar N, Haque ME, Khuda MIIE, Pervin MM, Khatun S, Hossain MI. 2006. Nutritional analysis of two varieties of papaya (Carica papaya) at different maturation stages. Pak J Biol Sci, 9: 137-140.

Bernfeld P. 1955. Amylase $\alpha$ and $\beta$. Methods in enzymology 1.S. P. Colswick and N.O.K., Ed. Academic Press Inc, New-York. 149154.

Choo CL, Azis NAA. 2010. Effects of banana flour and $\beta$-glucan on the nutritional and sensory evaluation of noodles. Food Chem, 119: 34-40.

Da Silva JAT, Rashid Z, Nhut DT, Sivakumar D, Gera A, Souza Jr MT, Tennant PF. 2007. Papaya (Carica papaya L.) Biology and Biotechnology. Tree For Sci Biotech, 1: 47-73.

Dubois M, Gilles KA, Hamilton JK, Rebers PA, Smith F. 1956. Colorimetric method for determination of sugars and related substances. Anal Chem, 28: 350-356.

Godim JAM, Moura MFV, Dantas AS, Medeiros RLS, Santos KM. 2005. Composição centesimal e de minerais em cascas de frutas. $L W T$-Food Sci and Technol, 25 (4): 825-827.

Gulcin I, Oktay M, Kirecc IE, Kufrevioglu OI. 2003. Screening of antioxidant and antimicrobial activities of anise (Pimpella anisum L.) seed extracts. Food Chem, 83: 371-382.

Meda A, Lamien CE, Romito M, Millogo J, Nacoulma OG. 2005. Determination of the total phenolic, flavonoid and proline contents in Burkina Fasan honey, as well as their radical scavenging activity. Food Chem, 91: 571-577.

Moure A, Cruz JM, Franco D, Domínguez JM, Sineiro J, Domínguez H, Núñez J, Parajó JC. 2001. Natural antioxidants from residual sources Food Chem, 72: 145-171.

N'Da AA, N'Guessan A, Djaha A, Hala N, Kouassi KN, Coulibaly F, Edo K, Zongo E. 2008. Bien cultiver le papayer en Côte d'Ivoire. Direction des programmes de recherche et de l'appui au développement - Direction des innovations et des systèmes d'information(CNRA), $4 p$ 
Ng LY, Ang YK, Khoo HE, Yim HS. 2012. Influence of Different Extraction Parameters on Antioxydants Properties of Carica papaya Peel and Seed. Res. Phytochem, 6(3):61-74.

Okonogi S, Duangrat C, Anuchpreeda S, Tachakittirungrod S, Chowwanapoonpohn S .2007. Comparison of antioxidant capacities and cytotoxicities of certain fruit peel. Food Chem, 103: 839-846.

Rinaldi MM, Lima TA, Ascheri DPR. 2010. Caracterização fisica de frutos de mamão e química de cascas e sementes. Planaltina: Embrapa Cerrados. Boletim de Pesquisa e Desenvolvimento, 263.

Sancho LEGG, Yahia EM, González-Aguilar GA. 2011. Identification and quantification of phenols, carotenoids, and vitamin C from papaya (Carica papaya L., cv. Maradol) fruit determined by HPLC-DAD-MS/MS-ESI. Food Res Int, 44: $1284-1291$.

Santos CM , Abreu CMP, Freire JM, Queiros ER, Mendonça MM. 2014. Chemical characterization of the flour of peel and seed from two papaya cultivars. Food Sci Technol, Campinas, 34(2): 353-357.

Shimada K, Fujikawa K, Yahara K, Nakamura T. 1992. Antioxidative properties of xanthan on the autoxidation of soybean oil in cyclodextrin emulsion. J. Agric. Food Chem, 40: 945-948.
Silva GG, Diniz RG, Silva ME. 2007. Avaliação química do mamão papaia (Carica papaya L.) em diferentes estádios de maturação. Revista Capixaba de Ciência e Tecnologia, 3: 1-7.

Singleton VL, Orthofer R, Lamuela-Raventos RM. 1999. Analysis of total phenols and other oxidation substrates and antioxidants by means of Folin-Ciocalteu reagent. Methods Enzymol, 299: $152-178$.

Thomás GE, Rodolfo HG, Juan MD, Georgina SF, Luis CG, Ingrid RB, Santiago GT. 2009. Proteolytic activity in enzymetic extracts from Carica papaya L. cv. Maradol harvest byproducts. Process Biochem, 44: 77-82.

Van Acker SA, Van Balen GP, Van Den Berg DJ, Bast A, Van Der Vijgh WJ. 1998. Influence of iron chelation on the antioxidant activity of flavonoids. Biochem. Pharmacol, 56: 935-43.

Werthera J, Saengera M, Hartgea E.-U, Ogadab T, Siagib Z. 2000. Combustion of agricultural residues. Prog Energy Combust Sci, 26: 1-27.

Yen GC, Duh PD, Tsai CL. 1993. Relationship between antioxidant activity and maturity of peanut hulls. J Agric Food Chem, 4: 6770 . 